Images in...

\title{
Coronary spasm: an unusual cause of ST elevation
}

Sumeet Sharma, ${ }^{1}$ Daniel Moffat, ${ }^{1}$ Diana A Gorog ${ }^{1,2}$

${ }^{1}$ Department of Cardiology, East \& North Hertfordshire NHS Trust, Welwyn Garden City, UK

${ }^{2}$ Imperial College, London, UK

Correspondence to Diana A Gorog, d.gorog@imperial.ac.uk

\section{DESCRIPTION}

A 48-year-old woman was referred for investigation of chest pain. While having a treadmill exercise tolerance test she developed marked ST-segment elevation with chest pain during stage 1 of the Bruce protocol (figure 1), which resolved promptly at the end of the exercise (figure 2 ).

The patient was transferred to the cardiac catheterisation laboratory for emergent coronary angiography. The left

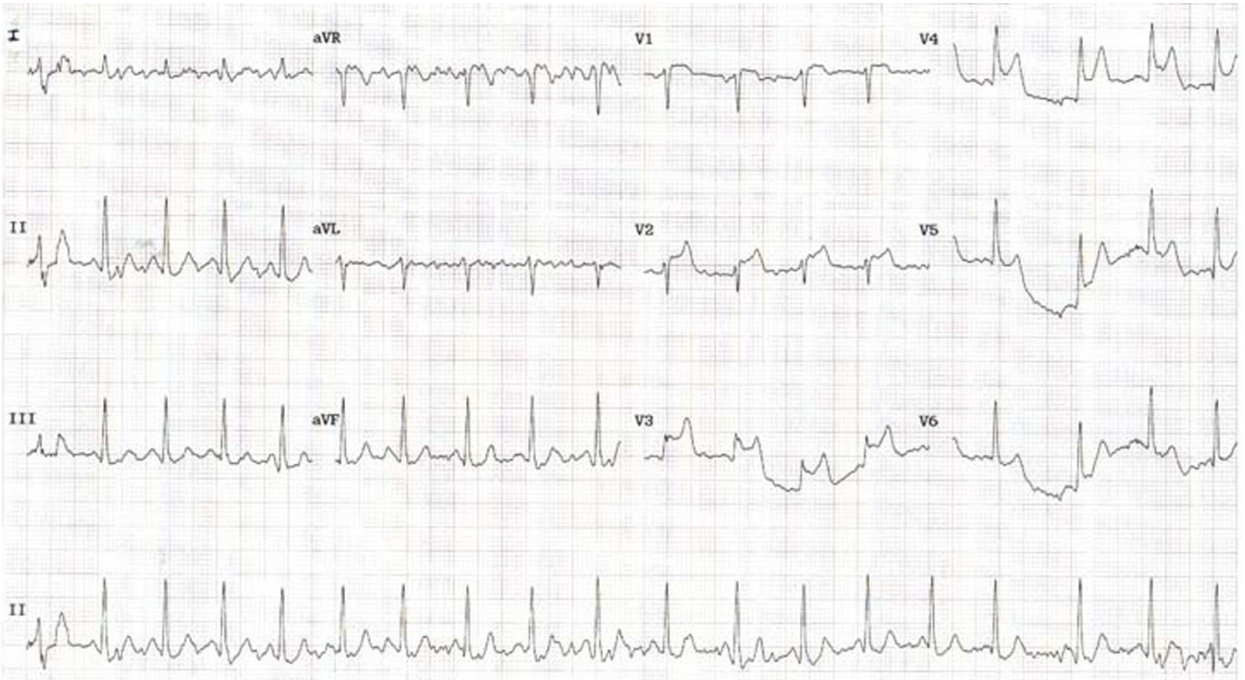

Figure 1 Exercise electrocardiogram (ECG) at stage 1 of the Bruce protocol showing ST elevation in leads V1-V5.

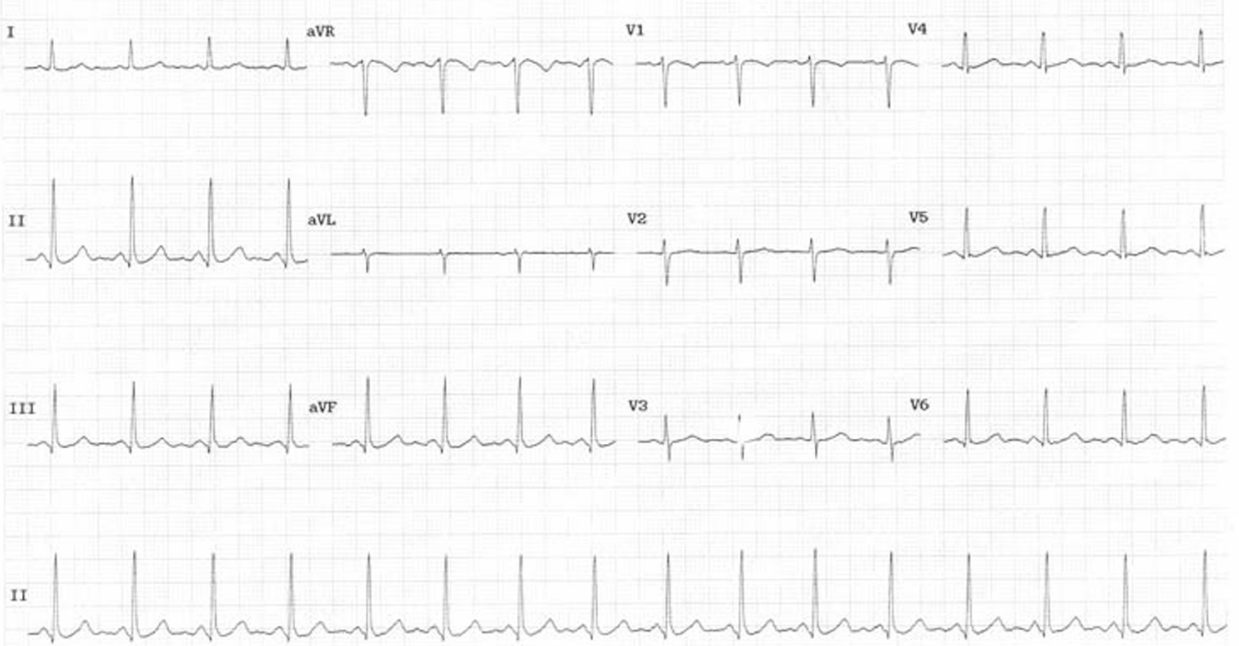

Figure 2 ECG showing normal sinus rhythm at rest. 


\section{BMJ Case Reports}

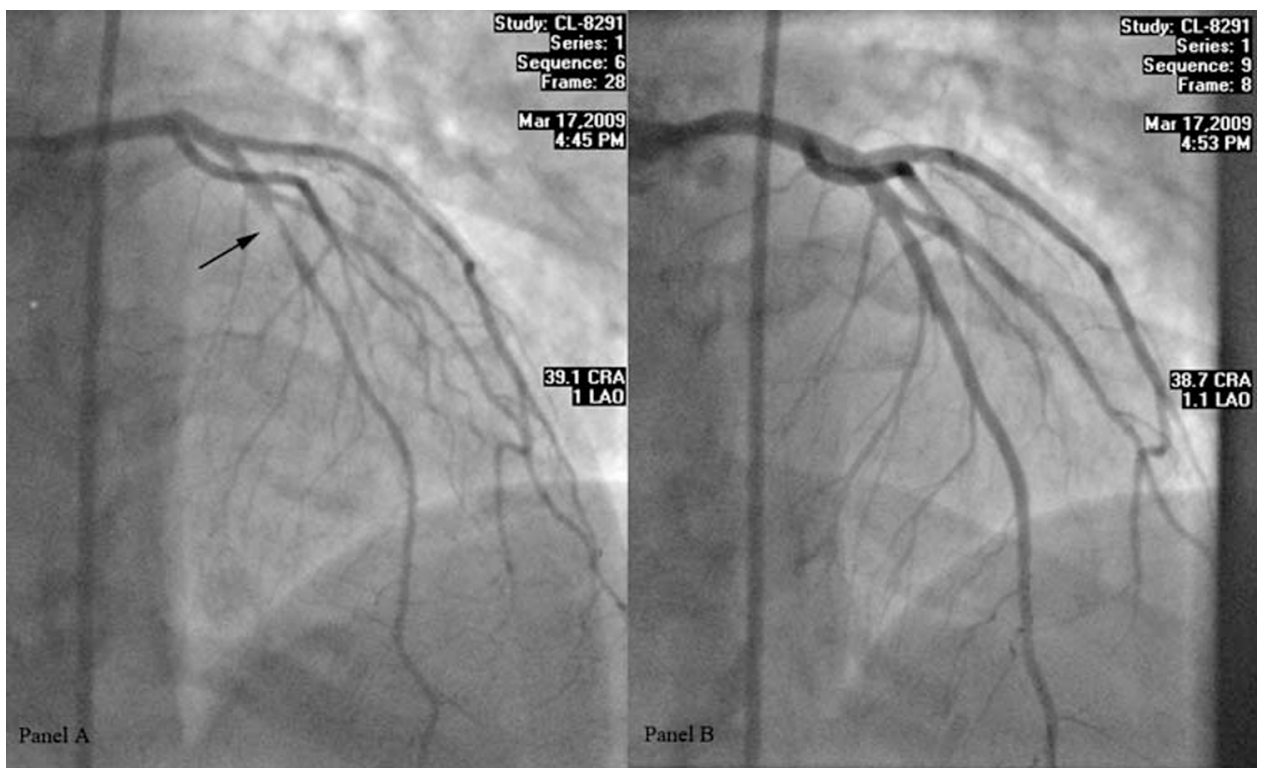

Figure 3 Coronary angiogram of left coronary system showing stenosis in left anterior descending (LAD) branch just beyond second diagonal branch $(A$, arrow), which resolved completely after administration of intracoronary nitrate $(B)$.

main stem, circumflex and the right coronary arteries were unobstructed. The left anterior descending (LAD) coronary artery showed a significant, smooth stenosis just beyond the second diagonal branch (figure $3 \mathrm{~A}$ ).

During the left coronary injections, the patient developed chest pain associated with dynamic anterior ST-segment elevation on the electrocardiogram (ECG).

An angioplasty guiding catheter was used to administer intracoronary isosorbide mononitrate $1.5 \mathrm{mg}$ into the left coronary artery. This resulted in vasodilatation and complete normalisation of the previously seen LAD stenosis (figure $3 \mathrm{~B}$ ). A diagnosis of severe coronary spasm causing an exercise-induced ST elevation was made and the patient was discharged home the next day on oral nitrates. Her cardiac enzymes were not elevated.

This case highlights coronary spasm, an unusual but well described cause of ST elevation and chest pain. ${ }^{1}$ It is important to recognise this syndrome, so that appropriate medi- cation may be instituted (such as nitrates, nicorandil or calcium channel blockers), $\beta$-blockers can be withdrawn, and so that inappropriate thrombolysis or angioplasty are not performed. The spectrum of presentation varies and thus the treatment and diagnostic modalities differ between individuals. The key to diagnosis is transient ST elevation concomitant with pain, as highlighted by Stern and Bayes de Luna in their recent review. ${ }^{2}$

\section{Competing interests None}

Patient consent Obtained.

\section{REFERENCES}

1. Ginsburg R, Schroeder JS, Harrison DC. Coronary artery spasm pathophysiology, clinical presentations, diagnostic approaches and rational treatment. West J Med 1982;136:398-410.

2. Stern S, Bayes de Luna A. Coronary artery spasm: a 2009 update. Circulation 2009;119:2531-4

This pdf has been created automatically from the final edited text and images.

Copyright 2010 BMJ Publishing Group. All rights reserved. For permission to reuse any of this content visit http://group.bmj.com/group/rights-licensing/permissions.

BMJ Case Report Fellows may re-use this article for personal use and teaching without any further permission.

Please cite this article as follows (you will need to access the article online to obtain the date of publication)

Sharma S, Moffat D, Gorog DA. Coronary spasm: an unusual cause of ST elevation. BMJ Case Reports 2010;10.1136/bcr.01.2010.2644, date of publication

Become a Fellow of BMJ Case Reports today and you can:

- Submit as many cases as you like

- Enjoy fast sympathetic peer review and rapid publication of accepted articles

- Access all the published articles

Re-use any of the published material for personal use and teaching without further permission

For information on Institutional Fellowships contact consortiasales@bmjgroup.com

Visit casereports.bmj.com for more articles like this and to become a Fellow 